\title{
Response of yams exposed to different sources and doses of nitrogen fertilizers in the State of Maranhão, Brazil
}

\author{
Resposta do inhame submetido a diferentes fontes e doses de \\ fertilizantes nitrogenados no Estado do Maranhão, Brasil
}

\author{
Francisco Nóbrega dos Santos ${ }^{1}$; Ademar Pereira de Oliveira ${ }^{2 *}$;

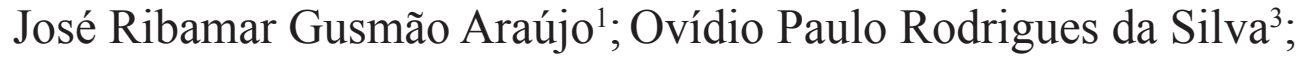 \\ Débora Tuane de Araújo Ferreira Silva'; Diego Almeida Medeiros ${ }^{3}$
}

\begin{abstract}
This study was carried out at the State University of Maranhão, São Luís, Brazil from January to November 2012. We assessed the behavior of the yam Dioscorea cayenensis 'Da Costa', fertilized with different rates and sources of nitrogen $(\mathrm{N})$. The experimental design was randomized, with treatments in a $6 \times 2$ factorial design. The factors were represented by six rates of $\mathrm{N}$ fertilization $(0,50,100$, 150,200 , and $250 \mathrm{~kg} \cdot \mathrm{ha}^{-1}$ ) and two sources (ammonium sulfate and urea) by using four replicates. We evaluated the mean mass, commercial root yield, leaf $\mathrm{N}$ content, starch content in the tubers, and percentage of tubers with symptoms of nematode infection (dry and thick skins). The maximum values for the mean masses of commercial tubers were 2.5 and $1.9 \mathrm{~kg}$ with doses of 130 and $160 \mathrm{~kg}$ of N $\mathrm{ha}^{-1}$ from ammonium sulfate and urea, respectively. Doses of 130 and $154.3 \mathrm{~kg}$ of $\mathrm{N} \mathrm{ha}{ }^{-1}$ produced the maximum yields of commercial tubers of 19.7 and $14.9 \mathrm{t} \cdot \mathrm{ha}^{-1}$ with ammonium sulfate and urea fertilization, respectively. The maximum levels of foliar $\mathrm{N}$ by using urea and ammonium sulfate were 36.5 and $29.3 \mathrm{~g} \cdot \mathrm{kg}^{-1}$, respectively, at a dosage of $250 \mathrm{~kg} \cdot \mathrm{ha}^{-1}$. The maximum starch contents of 25.7 and $28.3 \%$ were obtained at doses of 114 and $116 \mathrm{~kg}$ of N ha ${ }^{-1}$ of ammonium sulfate and urea, respectively. The percentage of tubers infected with nematodes was $10 \%$ when the $\mathrm{N}$ source was urea and $15.6 \%$ when the source was ammonium sulfate, both at a dosage of $250 \mathrm{~kg} \cdot \mathrm{ha}^{-1}$.
\end{abstract}

Key words: Dioscorea cayenensis, behavior, mineral fertilization, yield and quality of tubers

\section{Resumo}

O trabalho foi realizado na Universidade Estadual do Maranhão, São Luís, MA, no período de janeiro a novembro de 2012, com o objetivo de avaliar o comportamento do inhame (Dioscorea cayenensis), cultivar Da Costa, adubado com fontes e doses de N. O delineamento experimental utilizado foi blocos casualizados com os tratamentos distribuídos em arranjo fatorial $6 \times 2$, com os fatores foram representados por seis doses de $\mathrm{N}\left(0,50,100,150,200\right.$ e $\left.250 \mathrm{~kg} \mathrm{ha}^{-1}\right)$ e duas fontes (sulfato de amônio e ureia), em quatro repetições. Foram avaliados a massa média, produtividade comercial de túberas, teores de $\mathrm{N}$ foliar e amido nas túberas e percentagens de túberas com sintomas de ataque de nematóides (casca

${ }^{1}$ Profs., Dept ${ }^{\circ}$ de Fitotecnia e Fitossanidade, Centro de Ciências Agrárias, Universidade Estadual do Maranhão, UEMA, São Luís, MA, Brasil. E-mail: nobrega@cca.uema.br; gusmao@elo.com.br

2 Prof., Dept ${ }^{\circ}$ de Fitotecnia, Centro de Ciências Agrárias, Universidade Federal da Paraíba, UFPB, Areia, PB, Brasil. E-mail: ademar@cca.ufpb.br

3 Discentes do Curso de Doutorado em Agronomia, Programa de Pós-Graduação em Agronomia, UFPB, Areia, PB, Brasil. E-mail: ovidio_paulo@yahoo.com.br; diegoa083@gmail.com

4 Discente do Curso de Mestrado em Ciências do Solo, Programa de Pós-Graduação em Ciências do Solo, UFPB, Areia, PB, Brasil. E-mail: deboratuane@yahoo.com.br

* Autor para correspondência 
seca e casca grossa). Os máximos valores para as massas médias de túberas comerciais foram 2,5 e 1,9 kg alcançados nas doses de 130 e $160 \mathrm{~kg} \mathrm{ha}^{-1}$ de $\mathrm{N}$, fonte sulfato de amônio e ureia, respectivamente. As doses de 130,0 e 154,3 $\mathrm{kg} \mathrm{ha}^{-1}$ de $\mathrm{N}$ foram responsáveis pelas produtividades máximas de túberas comerciais de 19,7 e 14,9 t ha ${ }^{-1}$, respectivamente, nas fontes sulfato de amônio e ureia. Os teores máximos de $\mathrm{N}$ foliar nas fontes ureia e sulfato de amônio foram respectivamente, de 36,5 e $29,3 \mathrm{~g} \mathrm{~kg}^{-1}$ na dose de 250 $\mathrm{kg} \mathrm{ha}^{-1}$. Os teores máximos de amido de 25,7 e $28,3 \%$ foram obtidos nas doses de 114 e $116 \mathrm{~kg} \mathrm{ha}^{-1}$ de $\mathrm{N}$, respectivamente, nas fontes sulfato de amônio e ureia. A percentagem de túberas infectadas por nematoides na fonte ureia foi $10 \%$ na dose de $250 \mathrm{~kg} \mathrm{ha}^{-1}$ e na fonte sulfato de amônio de $15,6 \%$.

Palavras-chave: Dioscorea cayenensis, comportamento, adubação mineral, produção e qualidade de túberas

\section{Introduction}

Yam (Dioscorea spp.) cultivation is of considerable social and economic importance in Northeast Brazil, especially in the states of Paraíba, Pernambuco, Bahia, Alagoas, and Maranhão, which are the largest producers (SILVA et al., 2012). In Maranhão, yam cultivation is limited to small-scale family farming, which often lacks the technology. The only cultivated species is D. alata, particularly the São Tomé cultivar. The introduction of the $D$. cayennensis 'Da Costa' could improve the agribusiness of yam in that state because it is suitable for internal markets and export (SANTOS, 2011).

Regardless of the species cultivated and despite the fact that these states have significant economic and social potential as well as appropriate climate and soil conditions for yam culture, the average return of investment is low. This may result from factors such as naturally low soil fertility and traditional farming practices, indicating the need for research in the application of fertilizers appropriate for yams (DANTAS et al., 2013). The correct use of fertilizers, including the right doses and the specific developmental stages could improve yam yield (OLIVEIRA et al., 2011).

A plant's nitrogen (N) requirements vary according to the developmental stage, and in some crops, excessive $\mathrm{N}$ can increase vegetative growth that could be detrimental to crop yield. In other plants, excessive $\mathrm{N}$ application could result in increased numbers of succulent leaves that are highly susceptible to diseases, which in turn result in decreased crop yield. The application of adequate doses of $\mathrm{N}$ fertilizers, therefore, is fundamental to achieving the optimal crop yield (AMADO et al., 2002; BARBOSA FILHO et al., 2004).

The most common sources of $\mathrm{N}$ in Brazilian agriculture are urea and ammonium sulfate (BARBOSA FILHO et al., 2004). Urea consists of $45 \%$ water-soluble $\mathrm{N}$ and easily adsorbs moisture from the air (hygroscopicity). In the soil, part of the $\mathrm{N}$ in urea is transformed into gaseous ammonia $\left(\mathrm{NH}_{3}\right)$, and subsequently, nitrate. Ammonium sulfate consists of $20 \% \mathrm{~N}$ and $23 \%$ water-soluble sulfur (S); it is a crystal and is less hygroscopic than urea (PRIMAVESI et al., 2004; ALVES et al., 2009).

Among the mineral nutrients present in the dry leaf matter of yams, $\mathrm{N}$ and potassium $(\mathrm{K})$ have the highest levels; these nutrients are directly derived from the soil. Vidal (2008) examined the N, phosphorus $(\mathrm{P})$, and $\mathrm{K}$ levels in yam $(D$. cayennensis Lam.) leaves, stems, tubers, and roots and found that the demand for $\mathrm{N}$ and $\mathrm{K}$ was higher than that for P. Oliveira et al. (2007) previously reported that $\mathrm{N}$ fertilizers impart positive effects on the production of commercial tubers of this species.

Yam quality is directly related to a balanced supply of macro- and micronutrients that increase its nutritional value (OLIVEIRA et al., 2002). The main factor that determines yam quality is starch level, which varies according to the applied fertilizer regimen (OLIVEIRA et al., 2006). Leonel and Cereda (2002) showed the superior potential yield of starch per hectare in yam tubers compared to that of the other tuberous tropical plants such as potato, arracacha, arrowroot, and saffron. 
The incidence of nematode infections in yam crops can be very severe in agricultural areas in Northeast Brazil, and contaminated tubers are discarded or sold at much lower prices than those for healthy tubers. Numerous species of nematodes are found in the root system of yams, the most notable being the root and tuber endoparasites Scutellonema bradys and Pratylenchus coffea. Tubers infected by these nematodes have low commercial value and suffer significant losses in storage as the nematodes reproduce and induce a type of rot called dry or black skin (KWOSEH et al., 2002).

In this study, we examined the behavior of $D$. cayennensis yams subjected to different doses and sources of $\mathrm{N}$ fertilizer, in São Luís, state of Maranhão, Brazil.

\section{Material and Methods}

The study was carried out from January to November 2012 at the State University of Maranhão, São Luís, Maranhão (02 $31^{\prime} 47^{\prime \prime} \mathrm{S}, 44^{\circ} 12^{\prime} 10^{\prime \prime} \mathrm{W}$, altitude $64 \mathrm{~m}$ above sea level). According to the Köppen classification, the climate type is Aw, tropical hot and wet, with the rainy season from January to June (mean precipitation: $2010 \mathrm{~mm}$ ) and dry season from July to December (mean precipitation: $180 \mathrm{~mm}$ ), annual mean temperature of $26.1^{\circ} \mathrm{C}$, and mean relative humidity of $88 \%$ (INSTITUTO NACIONAL DE METEOROLOGIA, 2009).

The soil of the experimental plots was classified as Red-Yellow Argisol according to Santos et al., (2013), with a sandy loam texture. Its physical and chemical properties were determined according to Embrapa (1997) and showed the following characteristics: $\mathrm{pH} \mathrm{CaCl}=5.20 ; \mathrm{Al}+\mathrm{H}=2.10$ $\mathrm{cmol}_{\mathrm{c}} \cdot \mathrm{dm}^{-3} ; \mathrm{Ca}+\mathrm{Mg}=3.70 \mathrm{cmol}_{\mathrm{c}} \cdot \mathrm{dm}^{-3} ; \mathrm{K}=90$ $\mathrm{mg} \cdot \mathrm{dm}^{-3} ; \mathrm{P}($ Mehlich $)=62 \mathrm{mg} \mathrm{dm}{ }^{-3}$; organic matter $=14 \mathrm{~g} \cdot \mathrm{kg}^{-1}$; course sand $=200 \mathrm{~g} \cdot \mathrm{kg}^{-1}$; fine sand $=$ $580 \mathrm{~g} \cdot \mathrm{kg}^{-1}$; silt $=80 \mathrm{~g} \cdot \mathrm{kg}^{-1}$; and clay $=140 \mathrm{~g} \cdot \mathrm{kg}^{-1}$. The soil was limed in November, 60 days before planting, with $1.37 \mathrm{t} \cdot \mathrm{ha}^{-1}$ of dolomitic limestone (PRNT: 90\%), broadcast on the surface and incorporated by harrowing to elevate the soil base saturation index to $80 \%$. Soil preparation consisted of ploughing, harrowing, and furrowing, and holemaking for planting.

The experimental design used was randomized blocks with four replications. Each treatment was distributed in a $6 \times 2$ factorial arrangement. The factors were six doses of $\mathrm{N}(0,50,100,150,200$, and $250 \mathrm{~kg} \cdot \mathrm{ha}^{-1}$ ) from two sources (ammonium sulfate and urea). Each experimental plot comprised 40 plants; four rows of 10 with a spacing of $1.20 \times$ $0.60 \mathrm{~m}$.

The fertilizers applied were $14 \mathrm{t} \cdot \mathrm{ha}^{-1}$ of cattle manure, $100 \mathrm{~kg} \cdot \mathrm{ha}^{-1}$ of $\mathrm{P}_{2} \mathrm{O}_{5}$, and $70 \mathrm{~kg} \cdot \mathrm{ha}^{-1}$ of $\mathrm{K}_{2} \mathrm{O}$ at planting. The experimental doses of $\mathrm{N}$ from the two sources were applied as top dressing in equal amounts 60, 90, and 120 days after planting. The sources of fertilizer for $\mathrm{P}_{2} \mathrm{O}_{5}$ and $\mathrm{K}_{2} \mathrm{O}$ were single superphosphate and potassium chloride, respectively.

Portions of seed tubers of the Da Costa cultivar were planted with a mean mass of $200 \mathrm{~g}$ and at a depth of about $10 \mathrm{~cm}$ on the mounds on either side of the furrows. The yams were staked using bamboo culms, one for each plant. During the crop's cycle, the plots were manually weeded, and the soil was hilled and watered using a micro-sprinkler every two days. Phytosanitary measures included the use of fungicides, thiophanate-methyl (Cercobin $\left.{ }^{\circledR} \mathrm{WG}\right)$, and copper oxychloride (Agrinose, Agripec Química e Farmacêutica S/A), sprayed at a concentration of $20 \%$ to control leaf blight (Curvularia eragrostidis).

The yams were harvested after nine months when the branches and leaves were desiccated, indicating physiological maturity and end of the yam's vegetative cycle. Mean mass and yield of commercial tubers were assessed. Tubers weighing between 0.7 and $3.0 \mathrm{~kg}$ were considered commercial grade (SANTOS, 1996). N, P, and K content were also determined in the leaves 150 days after planting, following the methodology described by Tedesco et al. (1995), starch levels of the fresh 
tubers were estimated using the analytical norms of the Instituto Adolfo Lutz (2008), and the percentage of tubers with symptoms of nematode infection was evaluated.

The data were subjected to ANOVA using the $\mathrm{F}$ test to compare mean squares and polynomial regression analysis to compare the effects of the different $\mathrm{N}$ doses on the characteristics under evaluation; linear and quadratic models were tested and the one showing the highest value for the coefficient of determination was chosen to explain the results. The statistical analyses were conducted using a software package (UFV - SAEG, 2008).

\section{Results and Discussion}

A significant $(P<0.005)$ effect from the interaction of sources and doses of $\mathrm{N}$ on the mean mass and productivity of the commercial tubers, levels of $\mathrm{N}$ in the leaves and of starch in the tubers, and on the percentage of tubers with symptoms of nematode infection was observed. The levels of $\mathrm{P}$ and $\mathrm{K}$ in the leaves were not affected by the treatments.

The maximum values for the mean mass of the commercial tubers, estimated by associated variables, were 2.5 and $1.9 \mathrm{~kg}$, obtained with doses of 130 and $160 \mathrm{~kg} \cdot \mathrm{ha}^{-1}$ of $\mathrm{N}$ from ammonium sulfate and urea, respectively (Figure 1). Ammonium sulfate increased the mean mass of the tubers by $24 \%$ compared to that using urea. The mean mass values of the tubers were high, regardless of the $\mathrm{N}$ source used, ranging from 0.7 to $3.0 \mathrm{~kg}$, satisfying the requirements for internal markets and export (SILVA et al., 2012) and suggesting that $\mathrm{N}$ plays an important role in the commercial quality of yam tubers. Oliveira et al. (2007) have confirmed the effect of $\mathrm{N}$ fertilization in increasing the mean mass of commercial yam tubers.

Figure 1. Mean mass of commercial yam tubers as a function of different $\mathrm{N}$ doses and its sources: Ammonium sulfate and urea.

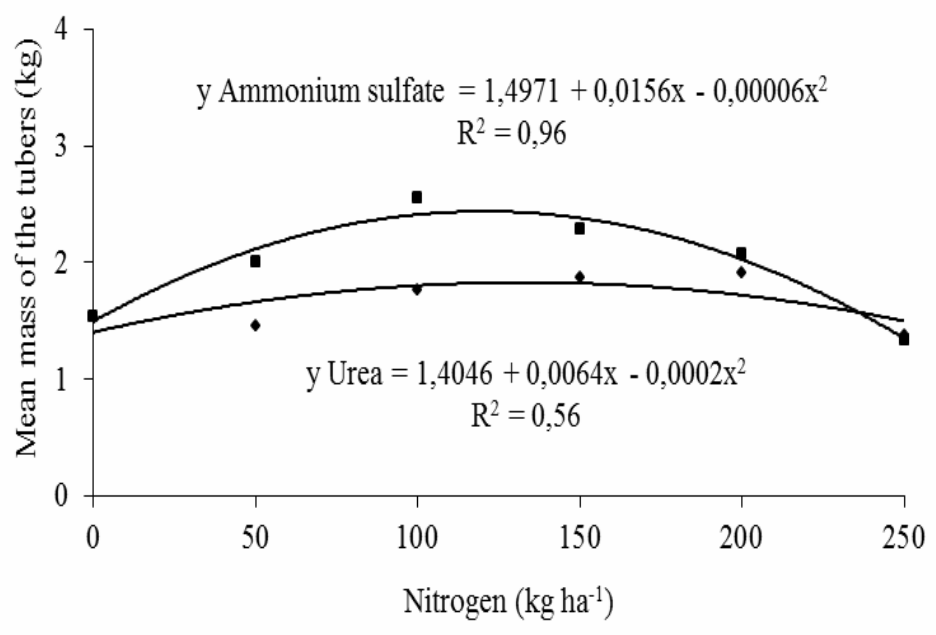

The doses of 130 and $154.3 \mathrm{~kg} \cdot \mathrm{ha}^{-1}$ of $\mathrm{N}$ were responsible for the maximum commercial tuber productivity levels of 19.7 and $14.9 \mathrm{t} \cdot \mathrm{ha}^{-1}$ fertilized with ammonium sulfate and urea, with increments of 47.3 and $30.3 \%$, respectively, when compared to those that were not fertilized with N (Figure 2). The productivity obtained with ammonium sulfate as the $\mathrm{N}$ source was higher than when urea was used, possibly due to the presence of $\mathrm{S}$ in the former $(23 \%)$. S plays a significant role in improving yields 
in the main commercial vegetables (OSÓRIO FILHO, 2006). According to Alves et al. (2009), the efficiency of $\mathrm{N}$ fertilization may be enhanced depending on the way it is provided, the timing of its application, and the source used, in order for farmers to maximize the economic benefits of its application.

Commercial productivity obtained using ammonium sulfate and urea as sources of $\mathrm{N}$ superseded by 9.7 and $4.9 \mathrm{t} \cdot \mathrm{ha}^{-1}$, respectively, the mean national productivity as reported by Mesquita (2002) at $10 \mathrm{t} \cdot \mathrm{ha}^{-1}$. Primary macronutrients are important in achieving high yam productivity. The greatest limiting factor of yield increase, however, is N (OLIVEIRA et al., 2007). According to Vidal (2008), the concentration of this nutrient is highest in the dry leaf matter and is one the elements that yams assimilate at the highest rate.

In the Brazilian Northeast, the general recommendation for the application of $\mathrm{N}$ for yam cultivation is $50-100 \mathrm{~kg} \cdot \mathrm{ha}^{-1}$ (OLIVEIRA et al., 2007). The doses responsible for maximum yam productivity in this study are higher than this range, showing that $\mathrm{N}$ should be supplied at doses that are much higher than that recommended by Oliveira et al. (2007) and that ammonium sulfate should be used as the source.

The need to apply $\mathrm{N}$ doses above those recommended for yam cultivation can be explained by the low initial organic content of the soil: $14 \mathrm{~g}$ $\mathrm{kg}^{-1}$ (MALAVOLTA, 2006). Organic matter content has been used to determine the availability of $\mathrm{N}$ for plants and, consequently, the need for crop fertilization (KOLCHINSKI; SCHUCH, 2003). Dantas et al. (2013) emphasized that soils with low organic matter content may imply low $\mathrm{N}$ availability for crops, and therefore, represent one of the chief limitations to agricultural productivity.
The reduced productivity of commercial tubers at high doses of $\mathrm{N}$ may indicate that excessive $\mathrm{N}$ could be harmful, possibly due to the toxic effect of ammonium and the low rate of nitrification, which causes serious damage to the crops, leading to reduced quality of the food because of elevated nitrate content. Amado et al. (2002) affirmed that in managing the nitrogen fertilization regime, it is important that the quantity of $\mathrm{N}$ in the crop be as accurate as possible, minimizing both excesses, which are harmful to the environment and increase production costs, as well as deficiencies, which compromise productivity.

The maximum foliar $\mathrm{N}$ content was 36.5 and $29.3 \mathrm{~g} \cdot \mathrm{kg}^{-1}$ using urea and ammonium sulfate, respectively, both at a dose of $250 \mathrm{~kg} \cdot \mathrm{ha}^{-1}$ of $\mathrm{N}$ (Figure 3). The figures were below the range of variation of $40-45 \mathrm{~g} \cdot \mathrm{kg}^{-1}$ that Malavolta et al. (1997) indicated as normal for tuber crops. Foliar $\mathrm{N}$ levels below those described in the present study were obtained by Oliveira et al. (2007) using ammonium sulfate as the $\mathrm{N}$ source. These figures show that the doses evaluated, regardless of the source, did not attain the plant's level of saturation for $\mathrm{N}$ absorption, and that the tendency for the level of $\mathrm{N}$ to increase in the leaves is because this element is one of the nutrients with the highest uptake by yams (VIDAL, 2008). On the other hand, the increasing accumulation of $\mathrm{N}$ in the leaves was not reflected in the increased commercial productivity of the tubers, which may indicate superfluous absorption and $\mathrm{N}$ assimilation continuing even after the yam had reached its maximum size (QUADROS et al., 2010). 
Figure 2. Commercial yam tuber productivity as a function of different $\mathrm{N}$ doses and its sources: Ammonium sulfate and urea.

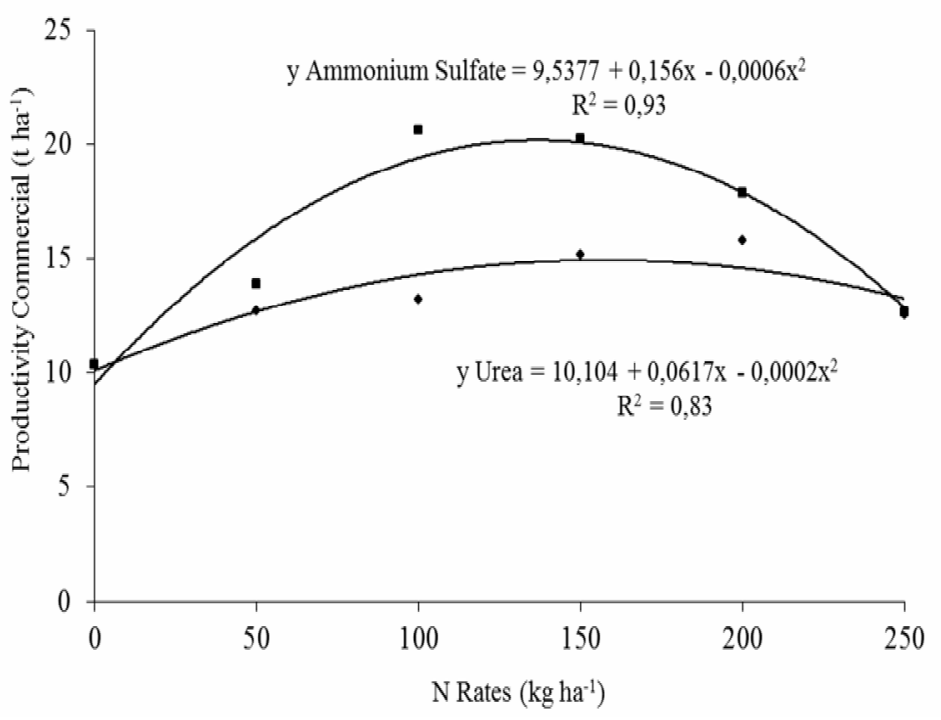

Figure 3. Yam leaf $\mathrm{N}$ content 150 days after planting as a function of $\mathrm{N}$ doses and sources.

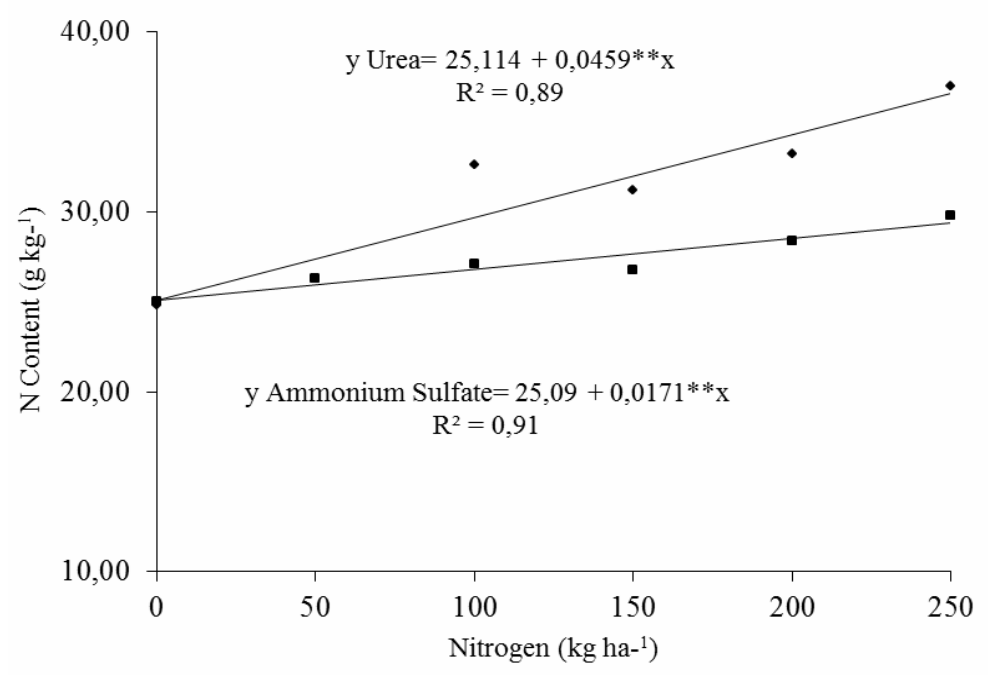

The maximum starch content in the tubers was 25.7 and $28.3 \%$ by using $\mathrm{N}$ doses of 114 and 116 $\mathrm{kg} \cdot \mathrm{ha}^{-1}$ of ammonium sulfate and urea, respectively (Figure 4). The starch content was in all cases within the range of $20-40 \%$ that is considered acceptable for the species (OLIVEIRA et al., 2002). As such, $\mathrm{N}$ can increase the starch content of yams. The decrease in starch content at elevated doses, however, indicates that inadequate application can result in a nutrient imbalance that affects the rate of starch biosynthesis (OLIVEIRA et al., 2006).

The percentage of tubers with infections by nematodes that cause dry skin was reduced with $\mathrm{N}$ doses using urea by at least $10 \%$ at the dose of $250 \mathrm{~kg} \cdot \mathrm{ha}^{-1}$, whereas when using ammonium sulfate as the source, the mean percentage was $15.6 \%$ (Figure 5). The decrease in yam yield due to nematode infection can be as high as $20-30 \%$ 
of fresh weight, most notably when the infection is due to nematodes that cause dry skin ( $S$. bradys and Pratylenchus spp.), which is considered to be the most important because of the wide distribution of the nematode species and large numbers of hosts (KWOSEH et al., 2002). According to Ritzinger and Fancelli (2006), $\mathrm{N}$ fertilization can be a viable alternative for the improvement of yam tuber health. Farming practices that reduce stress on the plants, N fertilization being one of them, have been found to reduce nematode populations in the soil.

Figure 4. Starch content of commercial yam tubers as a function of doses of $\mathrm{N}$ and its sources

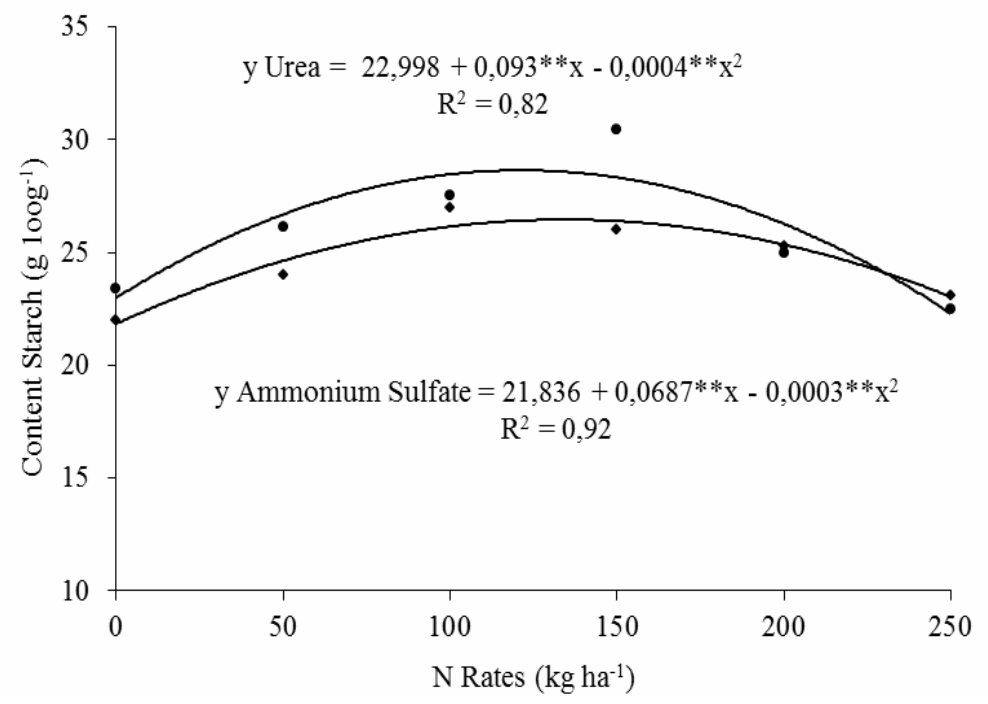

Figure 5. Percentage of yam tubers infected by nematodes as a function of doses of $\mathrm{N}$ and its sources

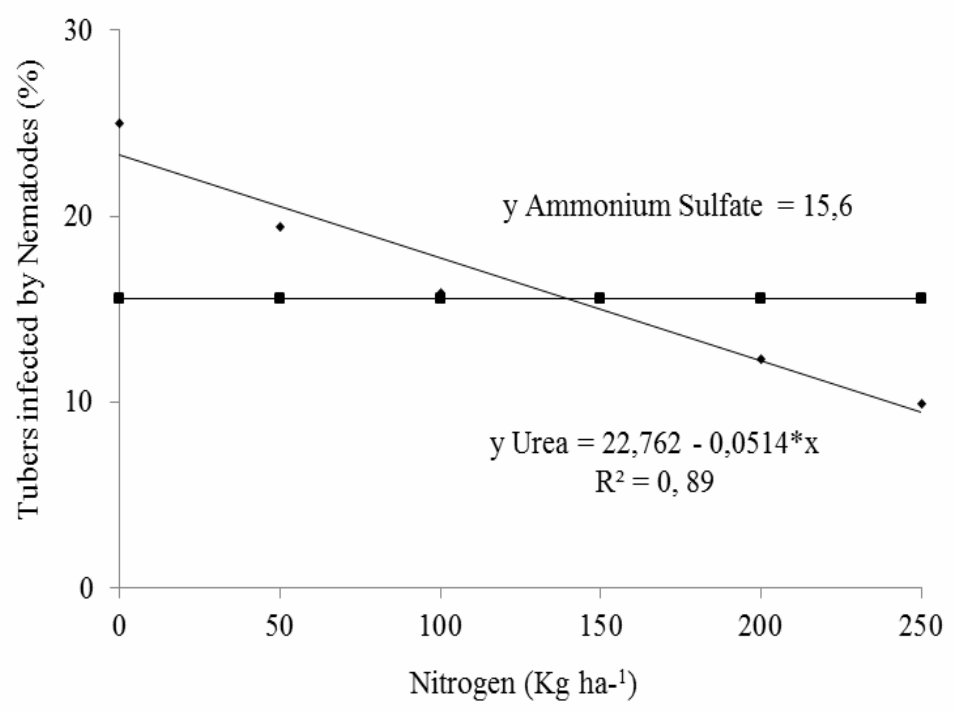




\section{Conclusions}

Increases in the mean mass and productivity were observed when yam crops were subjected to fertilization with ammonium sulfate and with urea, with the former showing superior performance than that by the latter. Further, greater increases in starch and foliar $\mathrm{N}$ contents were observed when the yam crops were fertilized with urea than with ammonium sulfate.

\section{References}

ALVES, A. U.; OliveirA, A. P.; AlVES, E. U.; OLIVEIRA, A. N. P.; CARDOSO, E. A.; MATOS, B. F. Manejo da adubação nitrogenada para a batatadoce: fontes e parcelamento de aplicação. Ciência e Agrotecnologia, Lavras, v. 33, n. 6, p. 1554-1559, 2009.

AMADO, T. J. C.; MIELNICZUK, J.; AITA, C. Recomendação de adubação nitrogenada para o milho no RS e SC adaptada ao uso de culturas de cobertura do solo, sob sistema plantio direto. Revista Brasileira de Ciência do Solo, Viçosa, MG, v. 26, n. 1, p. 241-248, 2002.

BARBOSA FILHO, M. P.; FAGERIA, N. K.; SILVA, O. F. Fontes e métodos de aplicação de nitrogênio em feijoieiro. Ciência Agrotecnológica, Lavras, v. 28, n. 4, p. 785-792, 2004.

DANTAS, T. A. G.; OLIVEIRA, A. P.; CAVALCANTE, L. F.; DAMIANA, F. D. A.; DANTAS, D. F. S.; BANDEIRA, N. V. S.; DANTAS, S. A. G. Produção do inhame em solo adubado com fontes e doses de matéria orgânica. Revista Brasileira de Engenharia Agrícola e Ambiental, Campina Grande, v. 17, n. 10, p. 1061-1065, 2013.

EMPRESA BRASILEIRA DE PESQUISA AGROPECUÁRIA - EMBRAPA. Centro Nacional de Pesquisa de Solos. Manual de métodos de análise de solo. Rio de Janeiro: Ministério da Agricultura, 1997.212 p.

INSTITUTO ADOLFO LUTZ - IAL. Métodos físicos e químicos para análises de alimentos. In: ZENEBON, O.; PASCUET, N. S.; TIGLEA, P. (Coord.). São Paulo: Instituto Adolfo Lutz, 2008. 1020 p.

INSTITUTO NACIONAL DE METEOROLOGIA INMET. Normas climatológicas do Brasil. Brasília: Ministério da Agricultura, 2009. 465 p.

KOLCHINSKI, E. M.; SCHUCH, L. O. B. Eficiência no uso do nitrogênio por cultivares de aveia branca de acordo com a adubação nitrogenada. Revista Brasileira de Ciências do Solo, Lavras, v. 27, n. 6, p. 1033-1038, 2003.

KWOSEH, C.; PLOWRIGHT, R.A.; BRIDGE, J. The yam nematode: Scutellonema bradys. In: STARR, J. L.; COOK, R.; BRIDGE, J. (Ed.). Plant resistance to parasitic nematodes. Wallingford: CABI Publishing, 2002. p. 221-228.

LEONEL, M.; CEREDA, M. P. Caracterização físicoquímica de algumas tuberosas amiláceas. Ciência e Tecnologia de Alimentos, Campinas, v. 22, n. 1, p. 65-69, 2002.

MALAVOLTA, E. Manual de nutrição mineral de plantas. São Paulo: Agronômica Ceres, 2006. 638 p.

MALAVOLTA, E.; VITTI, G. C.; OLIVEIRA, S. A. Avaliação do estado nutricional das plantas: princípios e aplicações. Piracicaba: POTAFOS, 1997. 201 p.

MESQUITA, A. S. Inhame e taro: cenários dos mercados internacional, brasileiro e baiano. Bahia Agrícola, Bahia, v. 5, n. 2, p. 54-64, 2002.

OLIVEIRA, A. N. P.; OLIVEIRA, F. A.; SOUSA, L. C.; OLIVEIRA, A. P.; SILVA, J. A.; SILVA, D. F.; SILVA, N. V.; SANTOS, R. R. Adubação fosfatada em inhame em duas épocas de colheita. Horticultura Brasileira, Brasília, v. 29, n. 4, p. 456-460, 2011.

OLIVEIRA, A. P.; BARBOSA, L. J. N.; PEREIRA, W. E.; SILVA, J. E. L.; OLIVEIRA, A. N. P. Produção de Rizóforos comerciais de inhame em função de doses de nitrogênio. Horticultura Brasileira, Brasília, v. 25, n. 1, p. 73-76, 2007.

OLIVEIRA, A. P.; BARBOSA, L. J. N.; SILVA, S. M.; PEREIRA, W. E.; SILVA, J. E. L. Qualidade do inhame afetada pela adubação nitrogenada e pela época de colheita. Horticultura Brasileira, Brasília, v. 24, n. 1, p. 22-25. 2006.

OLIVEIRA, A. P.; FREITAS NETO, P. A.; SANTOS, E.S. Qualidade do inhame 'Da Costa' em função das épocas de colheita e da adubação orgânica. Horticultura Brasileira, Brasília, v. 20, n. 1, p. 115-118, 2002.

OSÓRIO FILHO, B. D. Dinâmica de enxofre no sistema solo e resposta das culturas à adubação sulfatada. 2006. Dissertação (Mestrado em Ciência do Solo) Universidade Federal de Santa Maria, CCR, Santa Maria.

PRIMAVESI, A. C.; PRIMAVESI, O.; CORREA, L. A.; CANTARELlA, H.; SILVA, A. G.; FREITAS, A. R.; VIVALDI, L. J. Adubação nitrogenada em capimcoastcross: efeitos na extração de nutrientes e recuperação aparente do nitrogênio. Revista Brasileira de Zootecnia, Viçosa, MG, v. 33, n. 1, p. 67-78, 2004. 
QUADROS, B. R.; SILVA, E. S.; BORGES, L. S.; MOREIRA, C. A.; MORO, A. L.; VILLAS BÔAS, R. L. Doses de nitrogênio na produção de rabanete fertirrigado e determinação de clorofila por medidor portátil nas folhas. Irriga, Botucatu, v. 15, n. 4, p. 353-360, 2010.

RITZINGER, C. H. S. P.; FANCELLI, M. Manejo integrado de nematóides na cultura da bananeira. Revista Brasileira de Fruticultura, Jaboticabal, v. 28, n. 2, p. 331-338, 2006.

SANTOS, E. S. Inhame (Dioscorea ssp) aspectos básicos da cultura. João Pessoa: EMEPA-PB, SEBRAE. 1996. $158 \mathrm{p}$.

SANTOS, F. N. Comportamento do inhame Dioscorea cayennensis no Estado do Maranhão adubado com fontes e doses de nitrogênio. 2011. Tese (Doutorado em Agronomia) - Universidade Federal da Paraíba, CCA, Areia.

SANTOS, H. G.; JACOMINE, P. K. T.; ANJOS, L. H. C.; OLIVEIRA, V. A.; LUMBRERAS, J. F.; COELHO, M. R.; ALMEIDA, J. A.; CUNHA, T. J. F.; OLIVEIRA, J. B. Sistema brasileiro de classificação de solos. 3. ed. rev. e ampl. Brasília, DF: Embrapa, 2013. 353 p.
SILVA, J. A.; OLIVEIRA, A. P.; ALVES, G. S.; CAVALCANTE, L. F.; OLIVEIRA, A. N. P.; ARAÚJO, M. A. M. Rendimento do inhame adubado com esterco bovino e biofertilizante no solo e na folha. Revista Brasileira de Engenharia Agrícola e Ambiental, Campina Grande, v. 16, n. 3, p. 253-257, 2012.

TEDESCO, M. J.; GIANELLO, C.; BISSANI, C. A.; BOHNEN, H.; VOLKWEISS, S. J. Análise de solo, planta e outros materiais. Porto Alegre: UFRGS, 1995. $174 \mathrm{p}$.

UNIVERSIDADE FEDERAL DE VIÇOSA - UFV. SAEG: sistema para análise estatística, Versão 8.0. Viçosa, MG: Fundação Artur Bernardes, 2008.

VIDAL, C. R. M. Absorção de NPK na cultura do inhame (Dioscorea cayennensis Lam.) em três densidades de plantio. 2008. Dissertação (Mestrado em Ciências Agrárias) - Universidade Federal da Bahia, Cruz das Almas. 
